\title{
Influence of Trolox and Quercetin Combinations on Human Ovarian Cancer Cell Line A2780 and Human Breast Cancer Cell Line T47D-KBluc
}

\author{
Ileana MICLEA ${ }^{1) *}$, Vanda FUSS ${ }^{1)}$, Marius ZĂHAN ${ }^{1)}$, Delia ORLOVSCHI ${ }^{1)}$ and Vasile MICLEA ${ }^{1]}$ \\ 1) Department of Animal Reproduction, University of Agricultural Sciences and Veterinary Medicine, \\ 3-5, Mănăştur Street, 400372, Cluj-Napoca, Romania. \\ *Corresponding author, email: ileana.miclea@usamvcluj.ro
}

Bulletin UASVM Animal Science and Biotechnologies 72(2) / 2015

Print ISSN 1843-5262; Electronic ISSN 1843-536X

DOI:10.15835/buasvmcn-asb:11512

\begin{abstract}
Our aim was to investigate whether combining two powerful antioxidants such as Trolox and Quercetin could enhance their toxicity against breast and ovarian cancer cells. Human ovarian carcinoma cells from the A2780 line and human mammary gland carcinoma cells belonging to the T47D-KBluc line were incubated in RPMI-1640 supplemented with $50 \mu \mathrm{M}$ Trolox and various Quercetin concentrations $(25 \mu \mathrm{M}, 50 \mu \mathrm{M}$ and $100 \mu \mathrm{M})$. After 24 hours, several test were conducted: cells were stained with trypan blue and the number of viable versus dead cells was counted; cells were stained with Hoechst 33258 and propidium iodide to investigate the incidence of apoptosis and necrosis; cell activity and proliferation was assessed using the MTT test. In the A2780 line $50 \mu \mathrm{M}$ Trolox + $25 \mu \mathrm{M}$ Quercetin increased the number of apoptotic cells and enzyme activity in these cells, without influencing viability. On the other hand, in the T47D-KBluc line the $50 \mu \mathrm{M}$ Trolox $+100 \mu \mathrm{M}$ combination enhanced necrosis and thus reduced the percentages of metabolically active cells. Together with this concentration, a mix made of 50 $\mu \mathrm{M}$ Trolox and $25 \mu \mathrm{M}$ Quercetin also reduced cell viability. Our research indicates that in combination with Trolox, low concentrations of Quercetin induce apoptosis in human ovarian cancer cells, while high concentrations induce necrosis in human breast cancer cells. Quercetin concentrations influence this response significantly. Combining Quercetin with Trolox can enhance their toxicity against breast and ovarian cancer cells.
\end{abstract}

Keywords: human ovarian carcinoma, human mammary gland carcinoma, Quercetin, Trolox

\section{INTRODUCTION}

Breast cancer is one of the most common malignancies and it has a serious impact on female health (Deng et al., 2013). Worldwide, it is the most frequently diagnosed cancer and the leading cause of cancer death among females (Torre et al., 2012). Ovarian cancer is the most frequent cause of death among women with malignancies of the genital system (Siegel et al., 2015).

Despite the development of surgical techniques and chemotherapy, relapses occur very often especially in advanced cases (Deng et al., 2013). Therefore, the development of new antitumor substances is of paramount importance in the ongoing war against cancer. Some of the most widely employed chemotherapeutic drugs have been discovered and then perfected starting from natural sources (Cragg et al., 2011).

Among naturally occurring chemicals, flavonoids are considered promising food-derived chemo-preventive but also therapeutic agents against various human cancers (Sak, 2014). Quercetin, a naturally occurring flavonol, is one of the most abundant flavonoids found in many fruits and vegetables, such as broccoli, yellow onions, and apples (Boots et al., 2008). Some of its biological effects on both cancer and normal cells have been studied (reviewed in Gibellini et al., 2011). Previous in vitro research has shown that Quercetin acts as an antioxidant and anti- 
inflammatory agent and that it has potent anticarcinogenic properties as apoptosis inductor (Akan and Grip, 2013). Its activities include cell cycle regulation, interaction with type II estrogen binding sites and tyrosine kinase inhibition (Lamson and Brignall, 2001).

Trolox, the hydrophilic analogue of $\alpha$-tocopherol is also a powerful antioxidant that has been used to enhance the effect of other substances against myeloma, ovarian, and breast cancer cells (Diaz et al., 2005, Zheng et al., 2012) and combining it with Quercetin to achieve an enhanced toxicity against breast and ovarian cancer cells is an innovation of this study. To measure the effects of these combinations we evaluated cell viability, incidence of apoptosis and necrosis and proliferation.

\section{MATERIALS AND METHODS}

Cell culture, chemicals and media

Human ovarian carcinoma cells from the A2780 line, and human mammary gland carcinoma cells belonging to the T47D-KBluc line were were obtained from American Type Culture Collection (ATCC, USA). All chemicals were purchased from Sigma-Aldrich unless otherwise specified.

Human cancer cells A2780 and T47D-KBluc were cultured in RPMI-1640 supplemented with $2 \mathrm{mM} \mathrm{L}$-glutamine, $10 \%$ fetal bovine serum, $100 \mathrm{IU} / \mathrm{ml}$ penicillin (Intervet) and $100 \mu \mathrm{g} / \mathrm{ml}$ streptomycin (Intervet).

Trolox (6-hydroxy-2,5,7,8-tetramethyl3,4-dihydrochromene-2-carboxylic acid) and Quercetin (3,3',4',5,7-pentahydroxyflavone) were dissolved separately in 95\% ethanol to prepare stock solutions. These were added to the culture medium in the following concentrations: $50 \mu \mathrm{M}$ Trolox (50T), $50 \mu \mathrm{M}$ Trolox $+25 \mu \mathrm{M}$ Quercetin $(50 \mathrm{~T}+25 \mathrm{Q}), 50 \mu \mathrm{M}$ Trolox $+50 \mu \mathrm{M}$ Quercetin $(50 \mathrm{~T}+50 \mathrm{Q}), 50 \mu \mathrm{M}$ Trolox $+100 \mu \mathrm{M}$ Quercetin $(50 \mathrm{~T}+100 \mathrm{Q})$. Two controls were added to the experiment, one supplemented with $0.45 \%$ ethanol 95\% (Ctrl1) to test ethanol toxicity and one to which no addition had been made (Ctrl).

\section{Viability assay}

Cells belonging to the A2780 and T47DKBluc lines were seeded in $25 \mathrm{~cm}^{2}$ flasks allowed to adhere to the substrate within the space of 24 hours, and afterwards medium supplemented with the treatments was added. After being incubated with the various treatments for 24 hours, cell viability was analysed by staining with trypan blue. This vital stain enters dead cells making them appear dark blue and easy to differentiate from live cells that are light blue or transparent. Briefly, cells were harvested using trypsin and cell suspension mixed with trypan blue was loaded into a Bürker-Türk chamber. Live versus dead cells were counted and concentrations were computed using the formula below.

$$
\text { C }=\frac{n}{N} \times H \times S \times D
$$

$\mathrm{n}$ - number of counted cells;

$\mathrm{N}$ - number of squares from which cells were counted;

$\mathrm{H}$ - height of the chamber $(10 \mu \mathrm{m})$;

$\mathrm{S}$ - surface of a square $\left(1000 \mu \mathrm{m}^{2}\right)$;

D - dilution (100).

Concentrations of live and dead cells were used to compute percentages for both categories.

\section{Apoptosis and necrosis assay}

Tumour cells were seeded in $35 \mathrm{~mm}$ Petri dishes containing sterile coverslips. Cells were allowed to adhere to the coverslips within the space of 24 hours, and afterwards medium supplemented with the treatments was added. After being incubated with the various treatments for 24 hours, coverslips with cells were washed with PBS and exposed to a mixture of Hoechst 33258 $(20 \mu \mathrm{g} / \mathrm{ml})$ and propidium iodide $(50 \mu \mathrm{g} / \mathrm{ml})$ for 10 minutes. Coverslips were mounted on glass slides and cells were analysed immediately using an Olympus BX51 epifluorescence microscope (Brady, 2004; Rahman et al., 2013). A minimum of 200 cells were counted and the number of cells for each cellular state was recorded. The percentages of apoptotic and necrotic cells were determined according to the following formulas (Brady, 2004):

Percentage of Apoptotic Cells $(\%)=\frac{(L A+D A)}{L N+L A+D N+D A} \times 100$

Percentage of Necrotic Cells $(\%)=\frac{D N}{L N+L A+D N+D A} \times 100$ 
Where LN - live cells with normal nuclei (blue chromatin with organized structure);

LA - live cells with apoptotic nuclei (bright blue chromatin that is highly condensed or fragmented);

DN - dead cells with normal nuclei (pink chromatin with organized structure);

DA - dead cells with apoptotic nuclei (bright pink or red chromatin that is, highly condensed or fragmented).

Cell proliferation and activity assay

TheeffectofTroloxandQuercetincombinations was measured by the MTT (2-(4,5-dimethyl-2thiazolyl)-3,5-diphenyl-2H-tetrazolium bromide) assay adapted from Mosmann (1983). Cells from the A2780 and T47D-KBluc lines were plated in 96well plates and cultured for 24 hours. Afterwards, medium was replaced with RPMI-1640 containing the treatments, and cells were incubated for an additional 24 hours. MTT dissolved in PBS $(0.5$ $\mathrm{mg} / \mathrm{ml})$ was added to each well $(150 \mu \mathrm{l} /$ well $)$ and cells were further incubated at $37^{\circ} \mathrm{C}$ for 2 hours. During this time, MTT was reduced by enzymes of live cell to a purple formazan product which was afterward, dissolved by adding $150 \mu \mathrm{l} /$ well DMSO. Then it was analysed by using a Synergy 2 MultiMode Reader (BioTek) to measure absorbance at $550 \mathrm{~nm}$ and $630 \mathrm{~nm}$. The percentage of cell viability was calculated according to the following equation:

$$
\begin{aligned}
& \text { Cell activity }(\%)= \\
& \frac{\text { Treatment }_{550}-\text { Treatment }_{630}}{\text { Control }_{550}-\text { Control }_{630}} \times 100
\end{aligned}
$$

Where: Treatment $A_{550}-$ absorbance at $550 \mathrm{~nm}$ for each treatment;

Treatment $A_{630}-$ absorbance at $6300 \mathrm{~nm}$ for each treatment;

Control $A_{550}$ - absorbance at $550 \mathrm{~nm}$ for the control;

Control $\mathrm{A}_{630}$ - absorbance at $650 \mathrm{~nm}$ for the control.

\section{Statistical analysis}

The experiments were conducted in triplicates. For all experiments, one-way ANOVA with the Tukey-Kramer post-test was performed using GraphPad InStat version 3.05 for Windows 95 (GraphPad Software, San Diego California, USA). The values were considered statistically significant when $\mathrm{p}<0.05$.

\section{RESULTS AND DISCUSSION}

The working hypothesis was tested by assessing cell viability, incidence of apoptosis and necrosis and proliferation.

Cell viability was estimated using the trypan blue dye which penetrates dead cells but is excluded by living ones. After incubation with Trolox and Quercetin, the viability of cells from the A2780 line decreased in a progressive manner as the flavonoid concentration increased, but without statistically significant differences (Tab. 1). The two tested substances had a marked influence on the viability of T47D-KBluc cells, which was significantly lower for those incubated with $50 \mu \mathrm{M}$ Trolox and $25 \mu \mathrm{M}$ Quercetin.

The incidence of apoptosis and necrosis was assessed by staining with Hoechst 33258 and propidium iodide. These are fluorescent dyes that enter the cell and allow differentiating between normal live cells, cells undergoing apoptosis that have blue chromatin and dead cells or cells with a damaged membrane that are progressing through necrosis and have bright pink or red chromatin.

For cells from the A2780 line (Tab. 2), apoptosis was significantly increased by the presence of either $50 \mu \mathrm{M}$ Trolox $+25 \mu \mathrm{M}$ Quercetin or $50 \mu \mathrm{M}$ Trolox $+50 \mu \mathrm{M}$ Quercetin in the culture media. On the other hand, the incidence of necrosis was not significantly altered by any of the treatments when compared with the control.

When we analysed results for the T47D-KBluc line (Tab. 3), the situation was reversed with the percentage of necrotic cells being significantly increased by the addition of $50 \mu \mathrm{M}$ Trolox +100 $\mu \mathrm{M}$ Quercetin to the culture media.

Cell proliferation was assessed by the MTT assay in which the dye is reduced by NAD(P)H-dependent oxidoreductases and dehydrogenases of metabolically active cells. This process is associated not only with mitochondria, but also with the cytoplasm (Berridge et al., 2005). Therefore, this assay measures enzyme activity in the analysed population of cells.

When A2780 cells were analysed (Tab. 4), enzyme activity was significantly enhanced by the 
Tab. 1. Percentages of live cells after incubation with Trolox and Quercetin

\begin{tabular}{ccc}
\hline Treatment & A2870 & T47D-Kbluc \\
\hline Ctrl & $84.77 \pm 0.42 \mathrm{a}$ & $77.75 \pm 1.25 \mathrm{a}$ \\
\hline Ctrl1 & $84.50 \pm 2.46 \mathrm{a}$ & $76.65 \pm 3.95 \mathrm{a}$ \\
\hline $50 \mathrm{~T}$ & $84.03 \pm 2.11 \mathrm{a}$ & $75.80 \pm 0.20 \mathrm{ac}$ \\
\hline $50 \mathrm{~T}+25 \mathrm{Q}$ & $84.63 \pm 1.13 \mathrm{a}$ & $55.15 \pm 5.15 \mathrm{~b}$ \\
\hline $50 \mathrm{~T}+50 \mathrm{Q}$ & $83.43 \pm 1.49 \mathrm{a}$ & $63.25 \pm 0.75 \mathrm{abc}$ \\
\hline 50T $+100 \mathrm{Q}$ & $80.20 \pm 4.45 \mathrm{a}$ & $66.75 \pm 1.45 \mathrm{abc}$ \\
\hline Note: Values expressed are mean \pm standard error of the mean (SEM) of triplicate measurements. Different
\end{tabular}
was supplemented with $0.45 \%$ ethanol $95 \%$.

Tab. 2. Percentages of apoptotic and necrotic cells from line A2780 after incubation with Trolox and Quercetin

\begin{tabular}{ccc}
\hline Treatment & Apoptotic cells (\%) & Necrotic cells (\%) \\
\hline Ctrl & $37.00 \pm 4.33 \mathrm{a}$ & $39.60 \pm 7.07 \mathrm{ab}$ \\
\hline Ctrl1 & $45.16 \pm 2.42 \mathrm{ad}$ & $34.50 \pm 1.80 \mathrm{ab}$ \\
\hline $50 \mathrm{~T}$ & $42.30 \pm 0.19 \mathrm{ad}$ & $38.46 \pm 0.57 \mathrm{ab}$ \\
\hline $50 \mathrm{~T}+25 \mathrm{Q}$ & $58.00 \pm 0.50 \mathrm{bc}$ & $27.50 \pm 1.04 \mathrm{a}$ \\
\hline $50 \mathrm{~T}+50 \mathrm{Q}$ & $49.00 \pm 0.57 \mathrm{bcd}$ & $37.00 \pm 1.04 \mathrm{ab}$ \\
\hline $50 \mathrm{~T}+100 \mathrm{Q}$ & $46.00 \pm 0.50 \mathrm{a}$ & $46.16 \pm 0.88 \mathrm{~b}$ \\
\hline Note: Values expressed are mean + standard error of the mean (SEM) of triplicate
\end{tabular}

letters between means within the same column denote signifiant differences $(P<0.05)$. Medium in Ctr was supplemented with $0.45 \%$ ethanol $95 \%$.

combination of $50 \mu \mathrm{M}$ Trolox $+25 \mu \mathrm{M}$ Quercetin. The same mix increased $(P<0.05)$ enzyme activity in T47D-KBluc cells with the $50 \mu \mathrm{M}$ Trolox having a similar effect. An interesting development was the marked decrease $(P<0.05)$ in cell metabolism induced by $50 \mu \mathrm{M}$ Trolox $+100 \mu \mathrm{M}$ Quercetin.

Quercetin has been found to inhibit the growth of pancreatic cancer cells both in vivo and in vitro (Angst et al., 2013). It has also been found that its anticancer activity against leukaemia cells can be enhanced by certain water-soluble antioxidants (Chen et al., 2004). In erythroleukemia cells, concentrations above $100 \mu \mathrm{M}$ are toxic, while those below this limit increase viability (Akan and Garip, 2013). A similar effect, but with a threshold level of $40 \mu \mathrm{M}$ has been observed in ovarian cancer cells, if Quercetin was combined with anti-neoplastic agents such as Cisplatin, Taxol, Pirarubicin and 5-Fluorouracil (Maciejczyk and Surowiak, 2013; Li et al., 2014). In other studies, Quercetin inhibited the growth of breast cancer cells. The mechanism behind this effect could be the induction of apoptosis by triggering G0/G1 phase arrest (Deng et al., 2013).
Our results show that the response of cells to Trolox and Quercetin combinations depends on their type. These substances and particularly the $50 \mu \mathrm{M}$ Trolox $+25 \mu \mathrm{M}$ Quercetin mix induced apoptosis in cells form the A2780 line without influencing viability. However, enzyme activity in these cells was significantly increased.

Conversely, in T47D-KBluc cells necrosis was enhanced by supplementation with $50 \mu \mathrm{M}$ Trolox $+100 \mu \mathrm{M}$, a combination that also decreased the percentages of metabolically active cells. Together with this concentration, a mix made of $50 \mu \mathrm{M}$ Trolox and $25 \mu \mathrm{M}$ Quercetin reduced cell viability.

Apoptosis is a highly organized and coordinated form of cell death, which requires energy supplied by mitochondria under the form of ATP (Borutaite, 2010). It has been described as an active process (Gogvadze and Orrenius, 2006) and therefore enzyme activity in these cells is increased. These mechanisms are apparent in the case of A2780 ovarian cancer cells, which have a higher mitochondrial activity in the presence of certain Trolox and Quercetin concentrations. The apoptosis process is characterized by cell 
Tab. 3. Percentages of apoptotic and necrotic cells from line T47D-KBluc after incubation with Trolox and Quercetin

\begin{tabular}{ccc}
\hline Treatment & Apoptotic cells (\%) & Necrotic cells (\%) \\
\hline Ctrl & $52.83 \pm 4.84 \mathrm{a}$ & $28.50 \pm 5.77 \mathrm{a}$ \\
\hline Ctrl1 & $47.50 \pm 1.08 \mathrm{a}$ & $34.66 \pm 1.30 \mathrm{ab}$ \\
\hline $50 \mathrm{~T}$ & $58.33 \pm 2.96 \mathrm{a}$ & $29.50 \pm 3.05 \mathrm{a}$ \\
\hline $50 \mathrm{~T}+25 \mathrm{Q}$ & $54.00 \pm 2.29 \mathrm{a}$ & $28.33 \pm 3.18 \mathrm{a}$ \\
\hline $50 \mathrm{~T}+50 \mathrm{Q}$ & $48.16 \pm 0.60 \mathrm{a}$ & $40.16 \pm 0.88 \mathrm{ab}$ \\
\hline $50 \mathrm{~T}+100 \mathrm{Q}$ & $46.83 \pm 1.59 \mathrm{a}$ & $45.83 \pm 0.72 \mathrm{~b}$ \\
\hline
\end{tabular}

Note: Values expressed are mean \pm standard error of the mean (SEM) of triplicate measurements. Different letters between means within the same column denote significant differences $(P<0.05)$. Medium in Ctrl1 was supplemented with $0.45 \%$ ethanol $95 \%$.

Tab. 4. Effect of Trolox and Quercetin on cell activity

\begin{tabular}{ccc}
\hline Treatment & A2870 & T47D-Kbluc \\
\hline Ctrl & $100.00 \pm 0.00 \mathrm{a}$ & $100.00 \pm 0.00 \mathrm{a}$ \\
\hline Ctrl1 & $109.86 \pm 5.38 \mathrm{a}$ & $86.44 \pm 2.89 \mathrm{~b}$ \\
\hline $50 \mathrm{~T}$ & $91.31 \pm 3.21 \mathrm{a}$ & $123.73 \pm 3.79 \mathrm{c}$ \\
\hline $50 \mathrm{~T}+25 \mathrm{Q}$ & $149.15 \pm 5.89 \mathrm{~b}$ & $124.26 \pm 1.45 \mathrm{c}$ \\
\hline $50 \mathrm{~T}+50 \mathrm{Q}$ & $107.73 \pm 5.58 \mathrm{a}$ & $99.95 \pm 3.50 \mathrm{a}$ \\
\hline $50 \mathrm{~T}+100 \mathrm{Q}$ & $101.92 \pm 7.66 \mathrm{a}$ & $86.33 \pm 3.32 \mathrm{~b}$ \\
\hline
\end{tabular}

letters between means within the same column denote significant differences $(P<0.05)$. Medium in Ctrl1 was supplemented with $0.45 \%$ ethanol $95 \%$.

shrinkage, chromatin condensation, nuclear and cytoplasmic fragmentation and preservation of the plasma membrane barrier (Elmore, 2007). This makes it impossible for trypan blue and propidium iodide to enter the apoptotic cell (Nieminen, 2003) which can account for A2780 cell viability decreasing only slightly in the presence of the investigated substances.

In contrast to apoptosis, necrosis is a passive form of cell death (Gogvadze and Orrenius, 2006). Its distinctive features include mitochondrial depolarization and depletion of intracellular ATP, generation of reactive oxygen species and ultimately the collapse of the plasma membrane barrier. These events make possible the entrance of chemicals such as trypan blue and propidium iodide (Herman et al, 1988; Zong and Thompson, 2006). This could be the reason for the drop in cellular enzyme activity measured by MTT coupled with a higher incidence of necrosis encountered when $50 \mu \mathrm{M}$ Trolox $+100 \mu \mathrm{M}$ Quercetin were added to the culture medium of T47D-KBluc cells.

It is known that apoptosis and necrosis can be initiated in response to the same types of insults with different doses or intensities (Zong and Thompson, 2006). Our research indicates that in combination with Trolox low concentrations of Quercetin induce apoptosis in ovarian cancer cells while high concentrations induce necrosis in breast cancer cells. In both cell types, combinations of Trolox and Quercetin gave significantly better results than Trolox alone.

\section{CONCLUSION}

Experiments indicate that cells belonging to the human ovarian cancer cell line A2780 and the human breast cancer cell line T47Dkb-luc respond differently according to type to incubation with Trolox and Quercetin combinations. Quercetin concentrations influence this response significantly.

In the $\mathrm{A} 2780$ line $50 \mu \mathrm{M}$ Trolox $+25 \mu \mathrm{M}$ Quercetin increased the number of apoptotic cells and enzyme activity in these cells. On the other hand, in the T47Dkb-luc line the $50 \mu \mathrm{M}$ Trolox $+100 \mu \mathrm{M}$ combination enhanced necrosis and thus reduced the percentages of metabolically active cells. Combining Quercetin with Trolox 
can enhance their toxic activity against breast and ovarian cancer cells. Further research is still needed to explain the molecular mechanisms by which these processes take place in tumour cells.

\section{REFERENCES}

1. Akan Z, Garip AI (2013). Antioxidants may protect cancer cells from apoptosis signals and enhance cell viability. Asian Pac J Cancer Prev 14(8):4611-4614.

2. Angst E, Park JL, Moro A, Lu QY, Lu X, Li G, King J, Chen M, Reber HA, Go VL, Eibl G, Hines OJ (2013). The flavonoid quercetin inhibits pancreatic cancer growth in vitro and in vivo. Pancreas 42(2):223-229.

3. Berridge MV, Herst PM, Tan AS (2005). Tetrazolium dyes as tools in cell biology: new insights into their cellular reduction. Biotechnol Annu Rev 11:127-152.

4. Boots AW, Haenen GR, Bast A (2008). Health effects of quercetin: from antioxidant to nutraceutical. Eur J Pharmacol 585:325-337.

5. Borutaite V (2010). Mitochondria as decision-makers in cell death. Environ Mol Mutagen 51(5):406-416.

6. Brady HJM (2004). Apoptosis Methods and Protocols. Humana Press, Totowa, NJ, USA.

7. Chen J, Kang J, Da W, Ou Y (2004). Combination with water-soluble antioxidants increases the anticancer activity of quercetin in human leukemia cells. Pharmazie 59(11):859-863.

8. Chou CC, Yang JS, Lu HF, Ip SW, Lo C, Wu CC, Lin JP, Tang NY, Chung JG, Chou MJ, Teng YH, Chen DR (2010). Quercetinmediated cell cycle arrest and apoptosis involving activation of a caspase cascade through the mitochondrial pathway in human breast cancer MCF-7 cells. Arch Pharm Res 33(8):1181-1191.

9. Cragg GM, Kingston DGI, Newman DJ (Ed.) (2005). Anticancer agents from natural products. $2^{\text {nd }}$ ed. CRC Press, Boca Raton, FL, USA.

10. Deng XH, Song HY, Zhou YF, Yuan GY, Zheng FJ (2013). Effects of quercetin on the proliferation of breast cancer cells and expression of survivin in vitro. Exp Ther Med (5):1155-1158.

11. Diaz Z, Colombo M, Mann KK, Su H, Smith KN., Bohle DS, Schipper HM, Miller WH Jr. (2005). Trolox selectively enhances arsenic-mediated oxidative stress and apoptosis in APL and other malignant cell lines. Blood 105(3):12371245.

12. Elmore S (2007). Apoptosis: a review of programmed cell death. Toxicol Pathol 35(4):495-516.

13. Gibellini L, Pinti M, Nasi M, Montagna JP, De Biasi S, Roat E, Bertoncelli L, Cooper EL, Cossarizza A (2011). Quercetin and cancer chemoprevention. Evid Based Complement Alternat Med 2011:591356.

14. Gogvadze V, Orrenius S (2006). Mitochondrial regulation of apoptotic cell death. Chem Biol Interact 163(1-2):4-14.

15. Granado-Serrano AB, Martín MA, Bravo L, Goya L, Ramos S. (2006) Quercetin induces apoptosis via caspase activation, regulation of $\mathrm{Bcl}-2$, and inhibition of PI-3kinase/Akt and ERK pathways in a human hepatoma cell line (HepG2). J Nutr 136(11):2715-2721.

16. Herman B, Nieminen AL, Gores GJ, Lemasters JJ (1988). Irreversible injury in anoxic hepatocytes precipitated by an abrupt increase in plasma membrane permeability. FASEB J 2:146-151.

17. Lamson DW, Brignall MS (2000). Antioxidants and cancer, part 3: Quercetin. Altern Med Rev 5:196-208.

18. Li N, Sun C, Zhou B, Xing H, Ma D, Chen G, Weng D (2014). Low concentration of quercetin antagonizes the cytotoxic effects of anti-neoplastic drugs in ovarian cancer. PLoS One 9(7):e100314.

19. Mosmann T (1983). Rapid colorimetric assay for cellular growth and survival: application to proliferation and cytotoxicity assays. J Immunol Methods 65(1-2):55-63.

20. Maciejczyk A, Surowiak P (2013). Quercetin inhibits proliferation and increases sensitivity of ovarian cancer cells to cisplatin and paclitaxel. Ginekol Pol 84(7):590595.

21. Nieminen $\mathrm{Al}$ (2003). Apoptosis and necrosis in health and disease: role of mitochondria. Int Rev Cytol 224:29-55.

22. Rahman SNSA, Wahab NA, Malek SNA (2013). In Vitro Morphological Assessment of Apoptosis Induced by Antiproliferative Constituents from the Rhizomes of Curcuma zedoaria. Evidence-Based Complementary and Alternative Medicine volume 2013, article ID 257108, 14 pages.

23. Sak K (2014). Cytotoxicity of dietary flavonoids on different human cancer types. Pharmacogn Rev 8(16):122-146.

24. Siegel RL, Miller KD, Jemal A (2015). Cancer Statistics, 2015. CA Cancer J Clin 65:5-29.

25. Torre LA, Bray F, Siegel RL, Ferlay J, Lortet-Tieulent J, Jemal A (2015). Global Cancer Statistics, 2012. CA Cancer J Clin 65:87-108.

26. Zheng J, Payne K, Taggart JE, Jiang H, Lind SE, Ding WQ (2012). Trolox enhances curcumin's cytotoxicity through induction of oxidative stress. Cell Physiol Biochem 29(34):353-360.

27. Zong WX, Thompson CB (2006). Necrotic death as a cell fate. Genes Dev 20(1):1-15. 